16h - 17h30 | Aug. 23, 2017- Wednesday | ROOM 16

\title{
CONTENT PRODUCTION
}

\section{DRONES: FLYING REAL}

\section{Chair: Eduardo de Oliveira Silva Bicudo - Co-owner - EBCom ISET}

In this panel we intend to show three important aspects of Drone application in our work activity:

1. The commercialization and development of equipment. New technologies of control, size, load, cameras, sensors, etc ...

2. Use in the production department, such as soap opera, specific programs, news programs

3. The use in the RF transmission department of the TV networks This is a "tool" that has been showing endless applications in the various areas of knowledge. But everything has to go through the DRONE LEGAL, which you will watch before DRONE REAL.

\section{- REAL DRONE}

\section{Speaker: Eduardo Mascarenhas, Sócio da Peixe Voador Produções}

In this panel we will talk about the change of paradigms and main challenges in the use of Drones in series and soap operas. We will also talk about the type of equipment currently used in these productions, its characteristics and evolution.

\section{DRONES AND THEIR INNOVATIONS}

Speaker: Fernando Villares - Drones Brasil / Director

- TYPES, APPLICATIONS, BENEFITS AND SOFTWARE USED Speaker: Raquel Molina - Diretora Executiva da Futuriste

With the recent approval of the regulations in Brazil the use of Drones has expanded in several segments, mainly in the engineering sector where its use mainly results in reduction of costs, risks and increase the efficiency of professionals and companies in this segment. In this presentation we will explore the use of Drones in engineering, explaining which are the most used types and their characteristics, the main applications, their results, benefits and which are the software allied to these solutions.

- DRONE, A TOOL FOR ALL Speaker: Fábio Pardini Campesi - Operator - Ebcom 
The lecture aims to demonstrate the types and characteristics of Drones available in the market, as well as to explore the various applications mainly in the field of engineering and inspections.

\section{- Speaker: Vitor Ferrari Fozzatti - Operator - Ebcom}
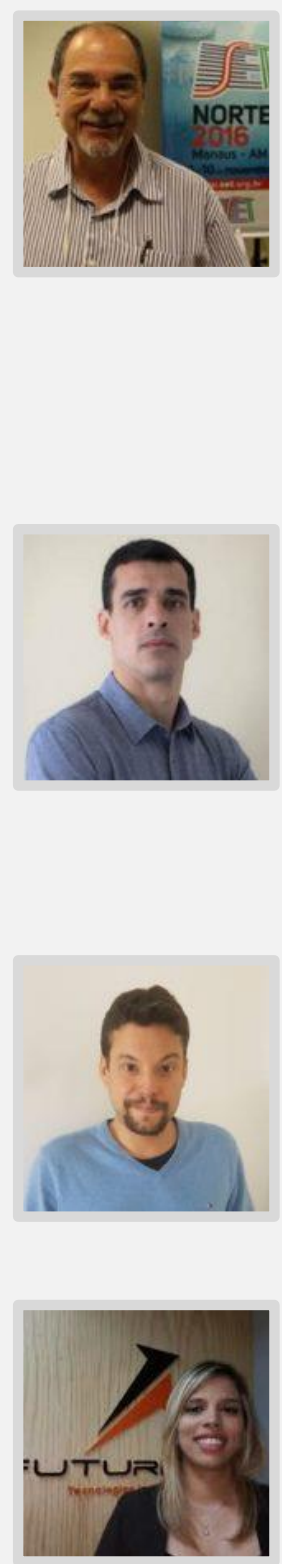

\section{Raquel Molina - Diretora Executiva da Futuriste}

Co-founder of Drones Futuriste Tecnologia, she is the company's executive director. She is considered the first woman instructor of Drones in Brazil, starting in the area in 2015. With a background in Technology, she has worked for several years as Systems Project Manager at major financial companies such as Itaú-Unibanco and Bradesco. Raquel holds a postgraduate degree in IT governance from Universidade Presbiteriana Mackenzie, an IT graduate with an Emphasis in Business Management from FATEC, Certified in ERP (Systems Requirements Engineering), certified in COBIT (IT Governance) and Technical Logistics by State Technical school.

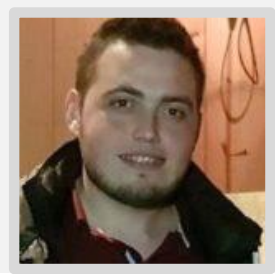

\section{Fábio Pardini Campesi - Operator - Ebcom}

Civil Engineering student at the Armando Alvares Penteado Foundation (FAAP), Aeromodelist for 10 years and 4 years working in the area of drones and multirotors. 


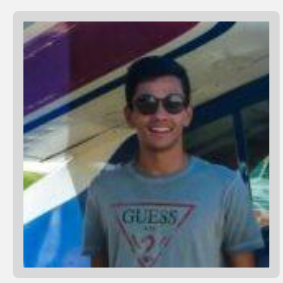

\section{Vitor Ferrari Fozzatti - Operator - Ebcom}

Aeromodelist for 10 years, where 4 of these were focused on drones research, operation and development. Commercial pilot of airplane in formation and student of Civil Aviation at Anhembi Morumbi University 